\title{
Different postharvest conditions modulate ripening and ethylene biosynthetic and signal transduction pathways in Stony Hard peaches
}

\author{
Maura Begheldo $^{\text {a }}$, George A. Manganaris ${ }^{a}$, Claudio Bonghi ${ }^{\text {a }}$, Pietro Tonutti ${ }^{b}$,* \\ a Department of Environmental Agronomy and Crop Science, University of Padova, Viale dell'Università 16, 35020 Legnaro (Padova), Italy \\ b Sant'Anna School of Advanced Studies, Piazza Martiri della Libertà 33, 56127 Pisa, Italy
}

Received 3 August 2007; accepted 18 September 2007

\begin{abstract}
Stony hard ( $\mathrm{SH})$ peaches are characterized, at ripening, by the maintenance of flesh firmness and the lack of ethylene production due to a reduced expression of Pp-ACS1. In a trial comparing melting flesh (MF, cv. 'Summer Rich') and SH ('IFF331' selection) fruit at two different postharvest temperatures $\left(10\right.$ and $\left.20^{\circ} \mathrm{C}\right)$, unexpected behaviour was observed in $\mathrm{SH}$ peaches that displayed an increase in ethylene production and a decrease in flesh firmness when stored at $10^{\circ} \mathrm{C}$, a temperature regime basically ineffective in delaying ripening in MF fruit. This appeared to be the result of an induction of $P p$-ACS1 transcription, making this genotype of particular interest for studying temperature stress physiology and ethylene-related ripening processes in peaches. Comparative expression analyses of genes involved in cell wall metabolism pointed out the presence of a negative $(P p-E G 4)$, positive $(P p$-endoPG) or no (one member of the $P L$ family) relationship with ethylene at ripening. Results clearly showed that the last stage of firmness decrease (melting) only occurs in fruit producing ethylene and is associated with $P p$-endoPG transcript accumulation. The expression of genes involved in ethylene biosynthesis and signalling pathways was evaluated using QRT-PCR. $P p$ - $A C O 1$ appeared to be induced in SH kept at $10^{\circ} \mathrm{C}$ but not at $20^{\circ} \mathrm{C}$. Transient increases in Pp-CTR1 and Pp-EIN2like gene expression have only been detected at the early stages of ripening in samples producing ethylene, indicating that a causal relationship might exist between ethylene and elements of its transduction pathway during peach fruit ripening.
\end{abstract}

(C) 2007 Elsevier B.V. All rights reserved.

Keywords: CTR1; EIN2; Ethylene biosynthesis; Ethylene signal transduction; Firmness; Temperature stress; Prunus persica (L. Batsch)

\section{Introduction}

Fruit ripening is a complex genetically-programmed physiological syndrome, defined by concurrent processes not necessarily interrelated from a regulatory point of view in both climacteric and non-climacteric fruit, the former characterized by increases in respiration and ethylene biosynthesis. Both ethylene-dependent and ethylene-independent regulatory mechanisms co-exist (Lelievre et al., 1997; Giovannoni, 2004) and isolation of tomato mutants has been particularly useful for identifying ripening- and ethylene-related processes (Giovannoni, 2007).

Peach (Prunus persica L. Batsch) is a climacteric fruit in which the increase in ethylene production occurs at an advanced stage of ripening (Tonutti et al., 1991). There is a typical biphasic pattern of loss of firmness in melting flesh (MF) peach geno-

\footnotetext{
* Corresponding author. Tel.: +39050883718; fax: +39050883210 .

E-mail address: pietro.tonutti@sssup.it (P. Tonutti).
}

types: the initial slow rate (softening) is followed by a rapid firmness decrease (melting) in correspondence to the onset of the ethylene climacteric (Tonutti et al., 1996). Stony hard (SH) fruit have crisp flesh at ripening and maintain high firmness values (both on- and off-tree), though they change colour normally and contain high soluble solids (Hayama et al., 2000; Haji et al., 2001, 2004). This behaviour is due to the lack of ethylene production and has been attributed to a single recessive gene ( $h d$ ) (Haji et al., 2001, 2005). Working with SH peaches (cv. 'Yumyeong'), Tatsuki et al. (2006) showed that ethylene production at ripening is inhibited by a reduced expression of Pp-ACS1, a member of the 1-aminocyclopropane-1-carboxylic acid (ACC) synthase gene family, which is responsible for the conversion of $S$-adenosyl-L-methionine to ACC, the immediate precursor of ethylene (Adams and Yang, 1979). Interestingly, in the same SH genotype, ethylene production increases and $P p-A C S 1$ transcripts accumulate in senescing flowers and in wounded immature and mature fruit (Tatsuki et al., 2006). The stony hard trait is inherited independently of the melting/nonmelting flesh trait and is epistatic to this trait. When treated 
with exogenous ethylene, mature $\mathrm{SH}$ peaches either ripen to the melting stage or just soften but never melt (Haji et al., 2005). The ethylene-promoted ripening is accompanied by increases in polygalacturonase (PG) gene expression and both endo- and exo-PG activity (Hayama et al., 2006a,b), but not by Pp-ACS1 mRNA accumulation (Tatsuki et al., 2006), and autocatalytic ethylene production does not take place. These findings clearly indicate that the stony hard locus is related to the regulation of $P p$-ACS1 expression and not to any disturbance of the ethylene perception and signal transduction pathways.

The ethylene biosynthesis pathway has been studied in detail in peach (reviewed in Ramina et al., 2007), and an increasing body of information is becoming available on ethylene receptors and elements involved in the signal transduction pathway in this fruit species. Two peach ethylene receptor genes, $P p$-ETRI and $P p-E R S 1$, have been isolated showing similar organization to that of the corresponding genes in Arabidopsis (Rasori et al., 2002). Unlike Pp-ETR1, Pp-ERS1 appears to be induced by ethylene and repressed by 1-methycyclopropene (1-MCP), an antagonist of ethylene action (Rasori et al., 2002). Using a genomic approach, Trainotti et al. (2006a) identified a new member of the peach ETR family, named Pp-ETR2, which shows increased expression during the transition from pre-climacteric to climacteric stage. The last part of the ethylene receptor complex is CTR1, which acts as a negative key regulator of ethylene responses. In climacteric fruit, such as tomato (Leclercq et al., 2002) and pear (El-Sharkawy et al., 2003), CTRl genes are upregulated during ripening and specific transcripts accumulate following exogenous application of ethylene. A decrease in $P p$ CTRl transcript accumulation has been observed by Dal Cin et al. (2006) in ripening peaches treated with 1-MCP, suggesting that CTRl is also ethylene-inducible in this fruit species. With regard to EIN2, the first positive regulator in the ethylene signalling cascade acting downstream from CTR1 (Guo and Ecker, 2004), Zhu et al. (2006) observed no changes in EIN2 transcript accumulation throughout tomato fruit ripening, whereas Wang et al. (2007) reported that an increase in Le-EIN2 gene expression occurs at the mature green-breaker stages. In peach fruit, an induction of a putative ortholog of EIN2 was observed during the transition from immature to mature stage (Trainotti et al., 2006a). However, preliminary microarray experiments did not clarify whether EIN2 transcription is affected by ethylene during peach fruit ripening (Begheldo et al., 2007; Tonutti et al., 2007).

The fact that in SH peaches (cv. 'Yumyeong') $P p$-ACS1 is normally expressed except in ripening fruit has been ascribed to the disruption of a transcription factor that is specifically activated to induce $P p$-ACS1 mRNA and/or the presence of inhibitors effective in suppressing $P p$-ACS1 expression at ripening (Tatsuki et al., 2006). Considering this aspect, and the fact that stress conditions (e.g. wounding) are effective in overcoming Pp-ACS1 inhibition and inducing ethylene production in 'Yumyeong' fruit (Tatsuki et al., 2006), SH peaches represent an interesting model to study factors controlling $P p$-ACS 1 transcription, mechanisms modulating its expression, and, using comparative approaches, to better elucidate ethylene physiology in ripening peach fruit.

\section{Materials and methods}

\subsection{Plant material}

Peach fruit (Prunus persica L. Batsch) of MF cultivar 'Summer Rich' and an SH phenotype 'IFF331' ('Hacuto' $\times$ 'New Jersey 256') obtained by the Istituto Sperimentale per la Frutticoltura of Forlì (Italy) were used in the experiments. Fruit were harvested at their commercial maturity stage and, after eliminating defective fruit, they were divided in two different groups (50 fruit each) and stored in ethylene-free air at $20^{\circ} \mathrm{C}$ and $10^{\circ} \mathrm{C}$ until the end of the experiment.

Flesh firmness $(N)$ was measured after removing a small disc of skin from each side of the fruit, using a penetrometer with an $8 \mathrm{~mm}$ probe. Epicarp and endocarp were removed and the mesocarp was frozen in liquid nitrogen and stored at $-80^{\circ} \mathrm{C}$ until required. Sampling days were selected based on the pattern of ethylene production.

\subsection{Ethylene production}

Ethylene biosynthesis was measured on 10 individual fruit at varying intervals, as described in Tonutti et al. (1991), by enclosing the fruit in $800 \mathrm{~mL}$ jars and withdrawing $1 \mathrm{~mL}$ of head space gas after $1 \mathrm{~h}$ incubation.

\subsection{Transcript analyses}

Total RNA was extracted as reported in Bonghi et al. (1998). Northern analysis (10 $\mu \mathrm{g}$ RNA) was performed as described in Ruperti et al. (2001), using molecular probes for pectate lyase (PL) (AJ532967) (Trainotti et al., 2003), endo-polygalacturonase (endo-PG) (AJ533395) (Trainotti et al., 2003) and endo- $\beta$-1,4-glucanase (EGase) (AJ890497.1) corresponding to $P p$-EG4 (Trainotti et al., 2006b).

Prior to quantitative real time-polymerase chain reaction (QRT-PCR), $30 \mu \mathrm{g}$ of total RNA was treated with 10 units of RQ1 RNase-free DNase (Promega) and 1 unit of RNAguard (RNase INHIBITOR) (Amersham) for $30 \mathrm{~min}$ and then purified by phenol-chloroform. One microgram of total DNA-free RNA was reverse-transcribed with 200 units of M-MLV reverse transcriptase (Promega), 1 unit of RNAguard and $2.5 \mu \mathrm{M}$ oligo$\mathrm{dT}_{12-18}$ primer at $37^{\circ} \mathrm{C}$ for $90 \mathrm{~min}$ in a final volume of $20 \mu \mathrm{L}$, as described in Sambrook et al. (1989). The single strand cDNA obtained $(100 \mathrm{ng})$ was subjected to real-time PCR in a final volume of $10 \mu \mathrm{L}$ containing $2 \times$ Power SYBR ${ }^{\circledR}$ Green PCR Master Mix (Applied Biosystems, Foster City, USA) and specific primers ( $3 \mathrm{pmol}$ ) for $P p$-ACO1, $P p$-ACS1, $P p$-CTR1, and $P p$-EIN2like (Table 1). Three technical replicates for each sample were run on an ABI 7500 Real Time PCR System Sequence Detection machine (PE Applied Biosystem) programmed to heat for $2 \mathrm{~min}$ at $50^{\circ} \mathrm{C}$ then $10 \mathrm{~min}$ at $95^{\circ} \mathrm{C}$, followed by 40 cycles of $15 \mathrm{~s}$ at $95^{\circ} \mathrm{C}$ and $30 \mathrm{~s}$ at $60^{\circ} \mathrm{C}$. Fluorescent detection was performed with an extra step of $35 \mathrm{~s}$ at temperatures varying in relation to each product's $T_{\mathrm{m}}$ (Table 1 ). The melting curves were checked for single peaks, and product size was confirmed in an agarose gel. The amplified cDNA fragments were cloned into 
Table 1

Primers (L: left and R: right) used in the real-time PCR mRNA quantification with specific detection step temperature

\begin{tabular}{lll}
\hline Gene & Primer L/R & $\begin{array}{l}\text { Detection } \\
\text { temperature }\left({ }^{\circ} \mathrm{C}\right)\end{array}$ \\
\hline R25S-5S & 5-TGAATTGCAGAATCCCGTGA-3 & 85.5 \\
& 5-TGACCTGGGGTCGCGTTGAA-3 & \\
$P p$-ACO1 & 5-GGGAAGTACAAGAGTGTGGAG- & 78 \\
& CACAGAG-3 & \\
& 5-CTTCTCCTCTGCTTCTTTCTC- & \\
& CACCAGTG -3 & 76.5 \\
$P p$ - $A$ CS1 & 5-ACCGAGACTTGGGATGGAGA-3 & \\
& 5-TGATCAAGCCCTTCACGTTG-3 & \\
$P p$-EIN2like & 5-ACAGCAGCTGGCGATGTAGC-3 & 77.5 \\
& 5-GTGAACCAGGACCCTCGTGA-3 & \\
$P p$ - CTR1 & 5-GCAAGACTTTCATGCCGAAC-3 & 74.5 \\
& 5-TATGGACAAGTTTGGGGGCT-3 & \\
\hline
\end{tabular}

pBluescript II KS + vector (Fermentas International, Burlington, Canada) and sequenced. For each gene, the PCR real-time efficiency was determined by measuring the fluorescence of four serial dilutions of the cDNA template. The expression values were calculated following the mathematical model proposed by Pfaffl (2001), using 25S-5S interspaced sequence as housekeeping.

\section{Results}

MF peaches kept at $20^{\circ} \mathrm{C}$ displayed typical ripening behaviour, with an initial stage of slow firmness decrease (softening) followed by the melting stage, leading to firmness values lower than $10 \mathrm{~N}$ at 8 days after harvest (DAH) (Fig. 1). If kept at $10^{\circ} \mathrm{C}$, MF peaches showed a similar pattern with slightly higher firmness values than those of control fruit. The melting stage was not delayed in $10^{\circ} \mathrm{C}$ MF peaches, indicating that this temperature regime has very limited effects on MF peach ripening. At $20^{\circ} \mathrm{C} \mathrm{SH}$ peaches showed no change in flesh firmness through-

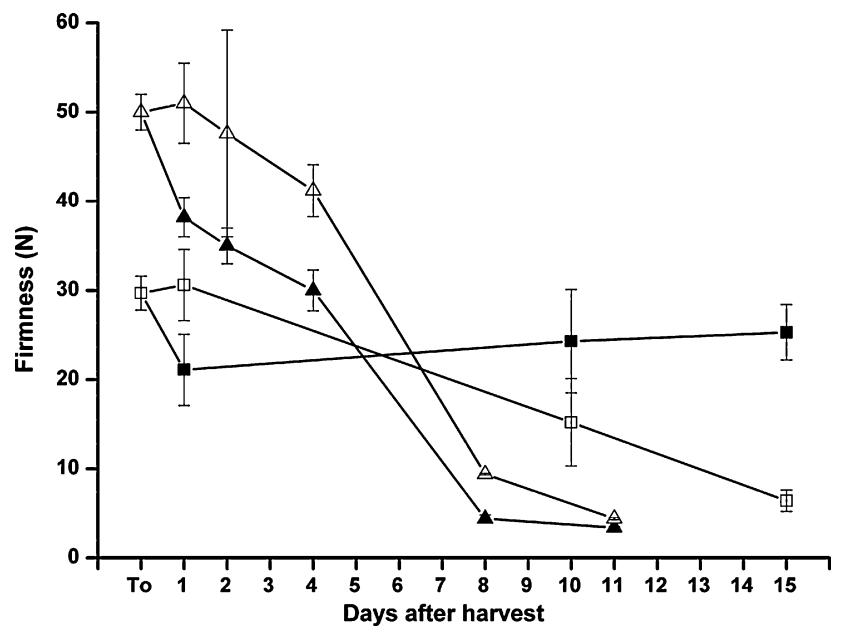

Fig. 1. Flesh firmness changes during postharvest ripening at different temperatures: cv. 'Summer Rich' at $20^{\circ} \mathrm{C}(\boldsymbol{\Delta})$ and $10^{\circ} \mathrm{C}(\triangle)$; 'IF331' selection at $20^{\circ} \mathrm{C}$ (ם) and $10^{\circ} \mathrm{C}(\square)$. Data are means of five replicates \pm S.E.

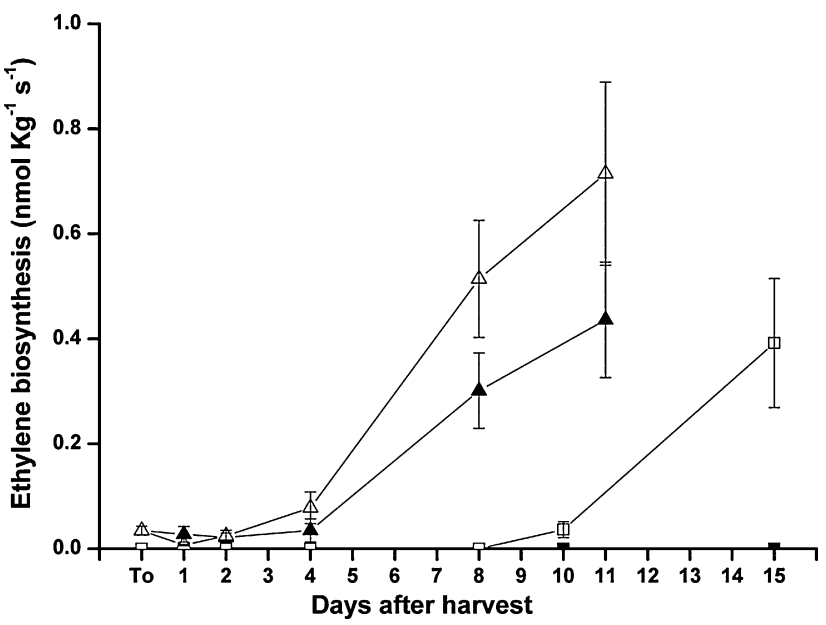

Fig. 2. Ethylene production during postharvest ripening at different temperatures: cv. 'Summer Rich' at $20^{\circ} \mathrm{C}(\boldsymbol{\Delta})$ and $10^{\circ} \mathrm{C}(\triangle)$; 'IF331' selection at $20^{\circ} \mathrm{C}$

) and $10^{\circ} \mathrm{C}(\square)$. Data are means of 10 replicates \pm S.E.

out the postharvest period, whereas, when the temperature was set at $10^{\circ} \mathrm{C}$, they unexpectedly started displaying lower firmness at $10 \mathrm{DAH}$, reaching values of about $10 \mathrm{~N}$ at $15 \mathrm{DAH}$ (Fig. 1).

In $\mathrm{MF}$ peaches the ethylene climacteric rise occurred at the melting stage, when the highest values of ethylene biosynthesis were observed in both samples (Fig. 2). No ethylene production was detected throughout the experimental period in $\mathrm{SH}$ peaches at $20^{\circ} \mathrm{C}$, while some was registered in $\mathrm{SH}$ fruit kept at $10^{\circ} \mathrm{C}$ at $10 \mathrm{DAH}$, followed by massive ethylene production at $15 \mathrm{DAH}$ (Fig. 2).

In order to elucidate this unexpected behaviour of $\mathrm{SH}$ peaches kept at $10^{\circ} \mathrm{C}$, expression of genes involved in ethylene biosynthesis was analysed by QRT-PCR. In MF peaches, transcript accumulation patterns confirmed that $P p$-ACOl was induced earlier than $P p$-ACS1 and that the ethylene climacteric was paralleled by a marked increase in transcript accumulation of $P p$-ACO1 (Fig. 4a), while a less pronounced increase in transcript levels of $P p$-ACS 1 was recorded at the melting stage (Day 11), when $P p$-ACS1 transcripts appeared to be higher in $\mathrm{MF}$ peaches kept at $10^{\circ} \mathrm{C}$ than the level observed in $20^{\circ} \mathrm{C}$ samples (Fig. 3a). Pp-ACS1 transcripts were almost undetectable in $\mathrm{SH}$ fruit stored at $20^{\circ} \mathrm{C}$, whereas if they were kept at $10^{\circ} \mathrm{C}$, a slight increase in Pp-ACS1 mRNA was observed $10 \mathrm{DAH}$ and a dramatic accumulation of specific transcripts was apparent after 15 days (Fig. 3b). In $\mathrm{SH}$ fruit, $P p$-ACOI transcripts remained at basal levels if fruit were kept at $20^{\circ} \mathrm{C}$, but not at $10^{\circ} \mathrm{C}$ when $P p-A C O 1$ resulted as being markedly expressed 10 and $15 \mathrm{DAH}$ (Fig. 4b).

The nature of the $\mathrm{SH}$ mutation and the peculiar ripening behaviour observed in $\mathrm{SH}$ fruit kept at $10^{\circ} \mathrm{C}$ make this genotype suitable for better elucidating the role of ethylene in the expression of ripening-related genes in peach fruit. Two elements involved in the ethylene signalling pathway were studied. Regarding Pp-CTRl, a transient increase of specific transcripts was present in fruit synthesizing ethylene (both MF samples and SH kept at $10^{\circ} \mathrm{C}$ ) (Fig. 5a and b) and the highest accumulation levels occurred in correspondence to the onset of ethylene climacteric. Compared to $\mathrm{SH}$ peaches kept at $10^{\circ} \mathrm{C}$, 

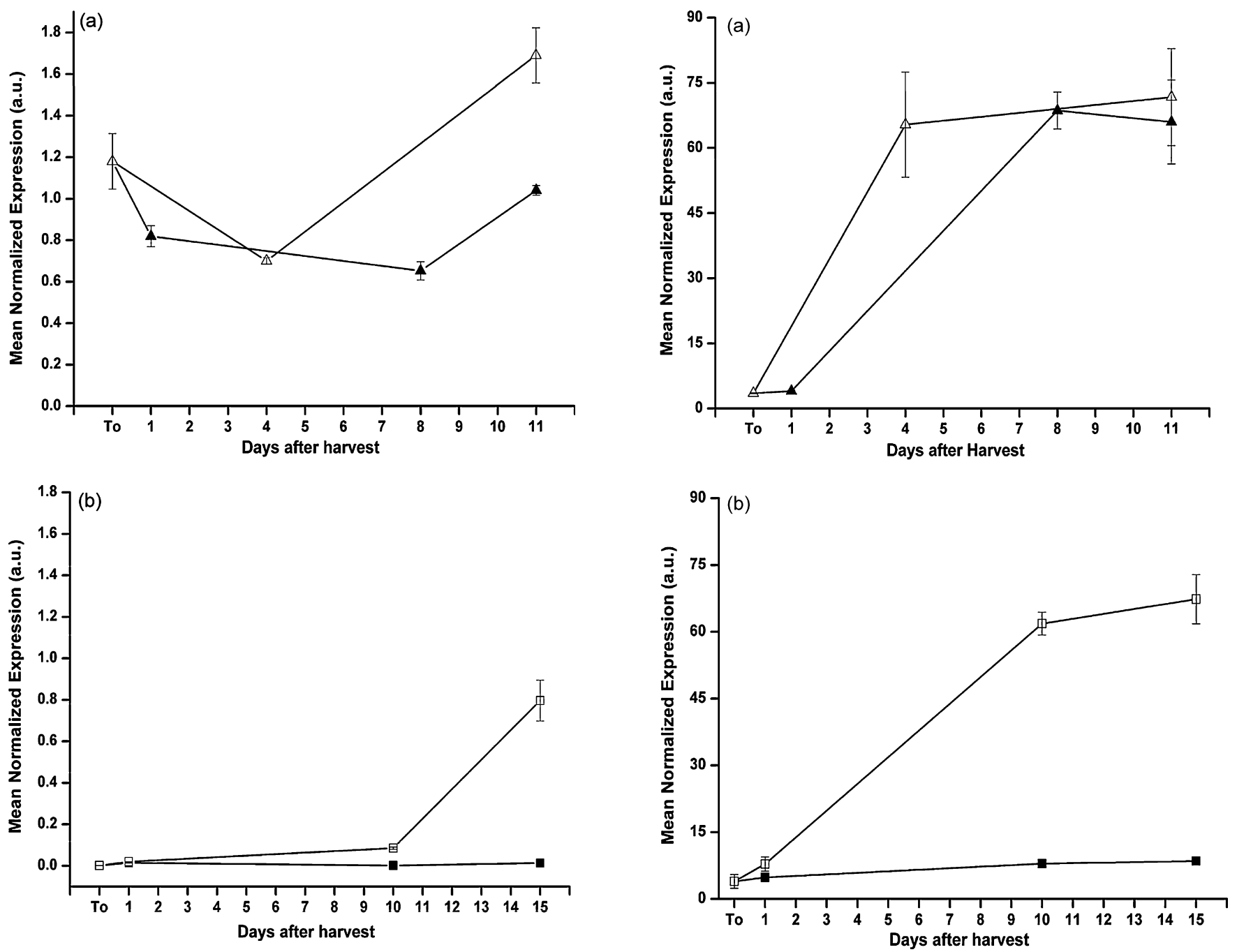

Fig. 3. $P p$-ACS1 transcript accumulation during postharvest ripening: (a) cv. 'Summer Rich' at $20^{\circ} \mathrm{C}(\boldsymbol{\Delta})$ and $10^{\circ} \mathrm{C}(\triangle)$; (b) 'IF331' selection at $20^{\circ} \mathrm{C}($ and $10^{\circ} \mathrm{C}(\square)$.

reduced transcript levels of $P p$-CTRl were observed in $20^{\circ} \mathrm{C}$ SH samples not producing ethylene (Fig. 5b). Similar results were obtained when Pp-EIN2-like transcript accumulation was quantified; again, a transient increase was present only in samples evolving ethylene and not in $\mathrm{SH}$ fruit at $20^{\circ} \mathrm{C}$, where a decreasing trend was monitored (Fig. 6a and b).

Given the different patterns of ethylene biosynthesis and loss of firmness detected in SH peaches kept at two temperature regimes during the postharvest period (Figs. 1 and 2), expression analyses of three cell wall-related genes were performed in SH, as well as in MF peaches for comparison (Fig. 7). $P p$ $E G 4$ expression showed a similar pattern in both MF samples; the highest expression level was detected at harvest, followed by a progressive reduction in transcript accumulation paralleling ethylene production. The same expression pattern was observed in $10^{\circ} \mathrm{C} \mathrm{SH}$ samples but not in $20^{\circ} \mathrm{C} \mathrm{SH}$ peaches, which maintained high levels of $P p E G 4$ expression throughout the experiment (Fig. 7a).

In analyzing the expression of two genes involved in pectin metabolism, the $P L$ gene showed no significant changes in both

Fig. 4. $P p-A C O 1$ transcript accumulation during postharvest ripening: (a) $\mathrm{cv}$. 'Summer Rich' at $20^{\circ} \mathrm{C}(\boldsymbol{\Delta})$ and $10^{\circ} \mathrm{C}(\triangle)$; (b) 'IF331' selection at $20^{\circ} \mathrm{C}(\boldsymbol{\square})$ and $10^{\circ} \mathrm{C}(\square)$.

genotypes and postharvest temperature conditions (Fig. 7b), whereas marked differences were detected in terms of endo- $P G$ transcript accumulation (Fig. 7c). In MF peaches the strongest hybridization signal occurred, for both samples, at the melting stage (11 DAH). In $\mathrm{SH}$ peaches kept at $20^{\circ} \mathrm{C}$, endo- $P G$ transcripts were not detected at harvest and $10 \mathrm{DAH}$, and a faint hybridization band appeared $15 \mathrm{DAH}$. When SH peaches were kept at $10^{\circ} \mathrm{C}$, a pronounced activation of endo- $P G$ gene transcription was observed at 10 and $15 \mathrm{DAH}$ in correspondence to the ethylene climacteric (Fig. 7c).

\section{Discussion}

The different ripening behaviour of stony hard compared to melting flesh peaches is the lack of ethylene production due to a suppression of Pp-ACS1 (Tatsuki et al., 2006). In the presence of exogenous ethylene, some $\mathrm{SH}$ peaches soften normally. This is the result of the induction of ethylene-dependent cell wall hydrolases, namely PGs, which show increases in both gene expression (Hayama et al., 2006a) and specific activity (Hayama 

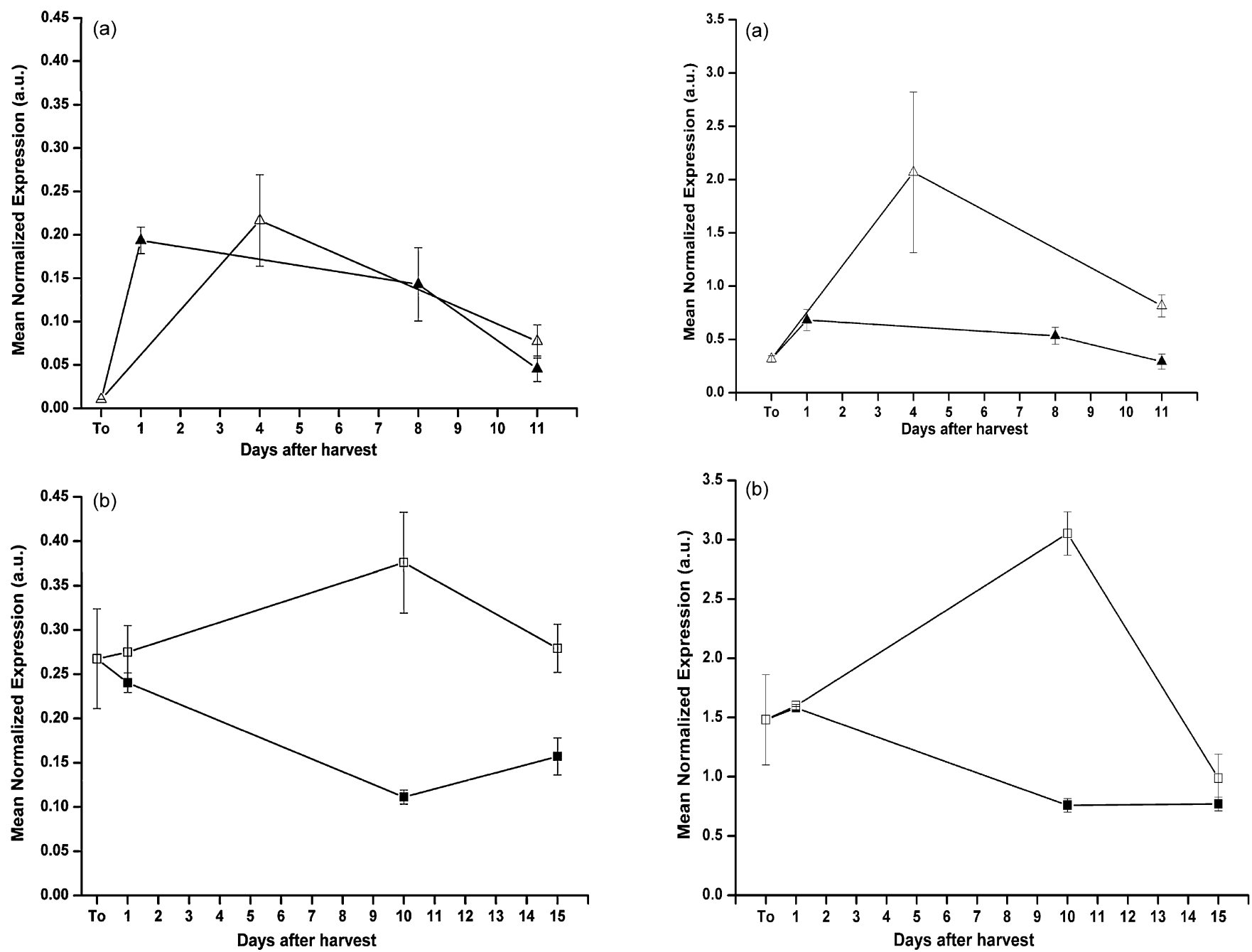

Fig. 5. $P p$-CTRl transcript accumulation during postharvest ripening: (a) cv. 'Summer Rich' at $20^{\circ} \mathrm{C}(\boldsymbol{\Delta})$ and $10^{\circ} \mathrm{C}(\triangle)$; (b) 'IF331'selection at $20^{\circ} \mathrm{C}(\mathbf{\square})$ and $10^{\circ} \mathrm{C}(\square)$.

Fig. 6. Pp-EIN2 like transcript accumulation during postharvest ripening: (a) cv. 'Summer Rich' at $20^{\circ} \mathrm{C}(\boldsymbol{\Delta})$ and $10^{\circ} \mathrm{C}(\triangle)$; (b) 'IF331' selection at $20^{\circ} \mathrm{C}$ (घ) and $10^{\circ} \mathrm{C}(\square)$.

"Summer Rich"

"IFF331"

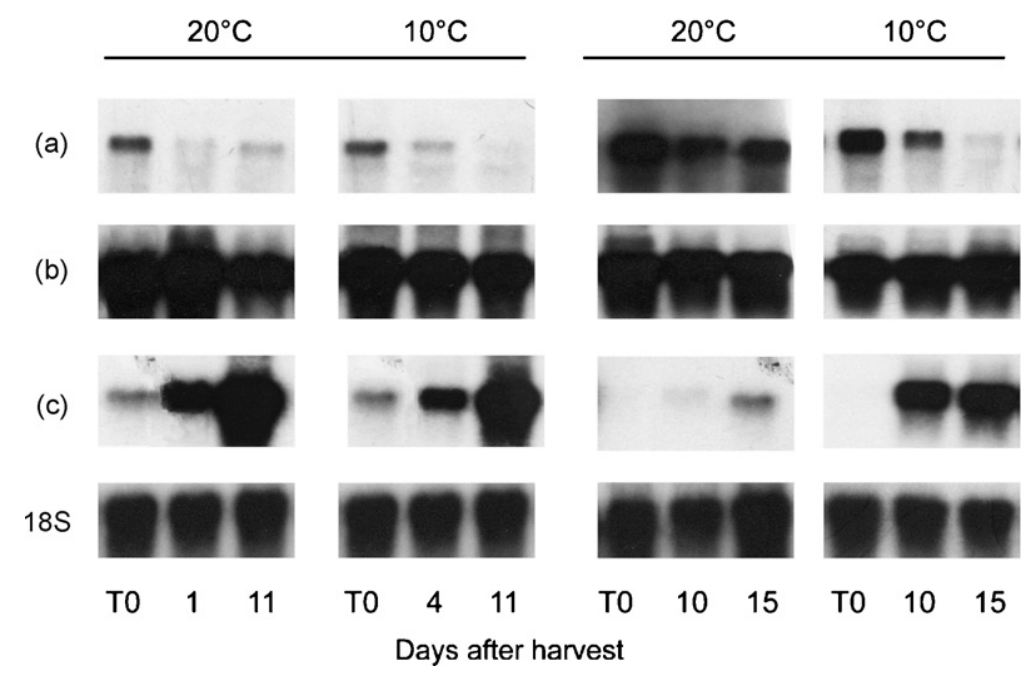

Fig. 7. Endo- $\beta$-1,4-glucanase (AJ890497.1) (a), pectate lyase (AJ532967) (b), and endo-polygalacturonase (AJ533395) (c) transcript accumulation, evaluated by northern analysis, in fruit of cv. 'Summer Rich' and 'IF331' selection during postharvest ripening at 10 and $20^{\circ} \mathrm{C}$. $18 \mathrm{~S}$ rRNA hybridisation was used to evaluate equal loading. 
et al., 2006b). Even in the presence of exogenous ethylene, $P p$ ACS1 is not expressed and ethylene is not produced in ripening SH fruit (Tatsuki et al., 2006). Based on this information, we can exclude that the loss of firmness detected in $\mathrm{SH}$ peaches kept at $10^{\circ} \mathrm{C}$ for 15 days is the result of the presence of exogenous ethylene, since a marked increase in $P p$-ACSI transcript, as well as ethylene biosynthesis, was clearly detected starting 10 DAH (Figs. 2 and 3). Similar results were obtained by Gamberini (2007) in 'Yumyeong' SH peaches stored at $4{ }^{\circ} \mathrm{C}$, where a slight increase in ethylene production was detected after 5 days with a high production following 10 days of storage under the same temperature conditions. Tatsuki et al. (2006) clearly showed that $P p$-ACS1 is expressed in ripening 'Yumyeong' peaches in response to wounding: taken together, these results indicate that stress conditions (wounding, low temperature) seem to be effective in overcoming $P p$-ACSI inhibition that has been ascribed, in $\mathrm{SH}$ peaches, to a disruption of a transcriptional factor specifically activated at ripening (Tatsuki et al., 2006). Interestingly, a temperature of $10^{\circ} \mathrm{C}$, basically ineffective in delaying ripening in MF peaches, appears to be perceived as a stress condition and is sufficient to remove PpACS1 inhibition in $\mathrm{SH}$ fruit. Experiments based on different temperature regimes and duration, the definition of the nature of stony hard phenotype, and the elucidation of mechanisms regulating $P p$-ACSI expression in $\mathrm{SH}$ peaches will be of great help in the attempt to identify the stress-induced factor that promotes $P p$-ACS1 transcription in this phenotype during ripening. The lack of ethylene production characterizing SH peaches and their behaviour when exposed to $10^{\circ} \mathrm{C}$ for several days make this genotype of particular interest for better elucidating the role of ethylene in regulating expression of different ripening-related genes.

Cell wall metabolism during peach fruit ripening is the result of changes in the activity of cell wall-targeted enzymes (Brummell et al., 2004; Brummell, 2006) encoded by genes differently affected by ethylene (Trainotti et al., 2003). We clearly demonstrate that PpEG4 is down-regulated by ethylene and that its expression is not related to the melting process. The different expression pattern of endo- $P G$ in $\mathrm{SH}$ fruit synthesizing ethylene $\left(10^{\circ} \mathrm{C}\right)$, or not $\left(20^{\circ} \mathrm{C}\right)$, reconfirms the relationship existing between this hormone, $P G$ transcription and melting stage as reported in early work on MF peaches (Downs et al., 1992), and, more recently, on SH peaches that displayed decreasing firmness values following exogenous ethylene treatment (Hayama et al., 2006a,b). The expression of the $P L$ gene, with no significant changes in either SH or MF samples throughout the experimental period, would indicate that its role in peach fruit melting is not as crucial as that played by $P G$. Considering results published by Benitez-Burraco et al. (2003) and Trainotti et al. (2003), we cannot exclude that other PLs, showing differential expression, may be active during peach ripening and/or that expression of the $P L$ studied in this work is differently modulated according to the genotype.

Some of the genes encoding multiple steps in the ethylene signal pathway are ethylene-inducible at ripening and this suggests a selective advantage for amplifying ethylene signalling machinery during climacteric fruit ripening (Adams-Phillips et al., 2004). The differences observed in Pp-CTR1 and Pp-EIN2 like expression pattern in $\mathrm{MF}$ and $\mathrm{SH}$ ripening peaches reinforce this hypothesis. Marked differences in the mRNA accumulation patterns of the two ethylene response components are present in fruit where ethylene biosynthesis is activated and the climacteric occurs (both $\mathrm{MF}$ samples and $\mathrm{SH}$ at $10{ }^{\circ} \mathrm{C}$ ) and fruit ( $\mathrm{SH}$ at $20^{\circ} \mathrm{C}$ ) characterized by lack of ethylene production. With CTR1, a positive relationship between the presence of the ethylene climacteric and a transient accumulation of $P p-C T R l$ transcripts is evident: our data are in agreement with Leclercq et al. (2002) who reported that, in tomato, Le-CTRl is induced by ethylene during fruit ripening, reinforcing the hypothesis of an important regulatory role played by CTR in ethylene-dependent events. Similar behaviour has been observed in 'Passe Crassane' pears, where a sharp transient increase in Pc-CTR $1 \mathrm{mRNA}$ occurs during the ethylene climacteric, while in the absence of ethylene evolution or in the presence of 1-MCP, Pc-CTRl transcripts fail to accumulate (El-Sharkawy et al., 2003). In Rosa hybrida flower opening, two $C T R$ genes (Rh-CTRl and $R h$-CTR2) are clearly expressed in an ethylene-dependent manner (Muller et al., 2002; Ma et al., 2006). The increase in Pp-CTRl expression in correspondence to the ethylene climacteric rise, together with the up-regulation of (at least) two ethylene receptors, $P p$ ERS1 (Rasori et al., 2002) and Pp-ETR2 (Trainotti et al., 2006a), support the hypothesis of an important role played by these elements in moderating ethylene response (Klee, 2002). It has been demonstrated that CTR1 acts as negative regulator (Hua and Meyerowitz, 1998), thus a decrease in the expression might be associated with an increase in ethylene sensitivity. In all fruit producing ethylene (both $\mathrm{MF}$ and $10^{\circ} \mathrm{C} \mathrm{SH}$ samples), Pp-CTRI transcript accumulation shows a similar pattern, with a peak at the early stage of ripening, followed by a decrease when ethylene is produced at high levels. As stated above, reduced expression of CTR I might be associated with an increase in sensitivity to ethylene. Hayama et al. (2006a) showed that although a doseresponse effect is present, exogenous ethylene concentrations as low as $0.1 \mu \mathrm{LL}^{-1}$ are enough to accelerate the softening process in 'Manamy' SH peaches. Further investigations are needed to demonstrate the possible correlation between the high sensitivity of SH peaches to ethylene and the reduced transcription of Pp-CTR1.

LE-EIN2 has been isolated in tomato, and its silencing delayed fruit development and suppressed the ethyleneinducible and ripening-related genes such as $E 4$ and $P G$ (Zhu et al., 2006), indicating that Le-EIN2 is an essential component of ethylene signalling during tomato fruit development, although, contrasting data have been published on its expression pattern. Zhu et al. (2006) reported that it is constitutively expressed throughout fruit development and ripening, whereas Wang et al. (2007) observed an increase in Le-EIN2 transcripts at mature green and breaker stages, followed by a decrease during advanced ripening. Our results, besides confirming data obtained by Trainotti et al. (2006a) that showed an up-regulation of $P p$ EIN2 like during the transition from immature to mature stage, clearly indicate that a transient increase in Pp-EIN2 like expression takes place in pre-climacteric fruit, followed by a sharp decrease in correspondence to the burst of ethylene production. Treatments of mature-green tomato fruit with exogenously 
applied ethylene or 1-MCP did not affect Le-EIN2 expression (Zhu et al., 2006; Wang et al., 2007). Similarly, we observed no changes in Pp-EIN2 like expression following 1-MCP treatment in ripening peaches when $P p$-EIN2 like is highly expressed (Tonutti et al., 2007). In our study, a transient increase of $P p$ EIN2 like transcript level was detected in correspondence to the ethylene climacteric rise. This behaviour suggests the presence of a positive relationship between ethylene and Pp-EIN2 like expression during the early stages of peach fruit ripening. However, we cannot exclude that other factors may be responsible for the different expression pattern of Pp-EIN2 like. Alonso et al. (1999) pointed out that, in Arabidopsis, EIN2 functions in at least two different signalling pathways and is involved in stress responses. If this is also the case for the two peach samples kept at $10^{\circ} \mathrm{C}$ remains yet to be elucidated.

In conclusion, we have demonstrated that $\mathrm{SH}$ peaches, characterized by the lack of ethylene production at ripening, recover the ability to synthesize ethylene when exposed to postharvest temperature stress and this has been exploited to elucidate the role of the hormone in gene expression regulation in ripening peaches. The unexpected behaviour of SH fruit kept at $10^{\circ} \mathrm{C}$ after harvest resembles what happens in winter pears that, in order to ripen, require a cold storage period effective in inducing ACS transcription, stimulating ethylene production and promoting softening (El-Sharkawy et al., 2003). In the absence of low temperature, ripening does not occur and pears remain firm. One ACS gene isoform ( $P c-A C S 1 a$ ) appears to be cold- and ethylene-dependent and, in winter pears, it represents the control point in the onset of autocatalytic (system 2) ethylene production (El-Sharkawy et al., 2004). Assuming that similar mechanisms operate in winter pears and $\mathrm{SH}$ peaches kept at low temperature and given that both species belong to the same family (Rosaceae), a comparative study of $\mathrm{SH}$ peach and winter pear $A C S 1$ promoters together with a large-scale analysis of transcriptome may help to identify (common) factors possibly involved in determining this ripening behaviour. Another future prospect is the elucidation of ripening-related changes in $\mathrm{SH}$ phenotypes stored at a range of low temperatures.

\section{Acknowledgements}

This research has been funded by the Italian Ministry of Research and University (MIUR), Cofin (PRIN) projects no. 2004079422 and 2006072159 coordinated by PT. G.A.M. is a recipient of an E.U. Marie Curie individual fellowship (Grant MEIF-CT-2006-038997). We thank Dr. A. Liverani of the Istituto Sperimentale per la Frutticoltura in Forlì (Italy) for providing fruit material.

\section{References}

Adams, D.O., Yang, S.F., 1979. Ethylene biosynthesis: identification of 1-aminocyclopropane-L-carboxylic acid as an intermediate in the conversion of methionine to ethylene. Proc. Natl. Acad. Sci. U.S.A. 76, 170174.

Adams-Phillips, L., Barry, C., Giovannoni, J., 2004. Signal transduction systems regulating fruit ripening. Trends Plant Sci. 9, 331-338.
Alonso, J.M., Hirayama, T., Roman, G., Nourizadeh, S., Ecker, J.R., 1999. EIN2, a bifunctional transducer of ethylene and stress responses in Arabidopsis. Science 284, 2148-2152.

Begheldo, M., Ziliotto, F., Rasori, A., Bonghi, C., 2007. The use of PEACH 1.0 to investigate the role of ethylene in the initiation of the peach fruit ripening. In: Ramina, A., Chang, C., Giovannoni, J., Klee, H., Perata, P., Woltering, E. (Eds.), Advances in Plant Ethylene Research: Proceedings of the 7th International Symposium on the Plant Hormone Ethylene. Springer, pp. 265-267.

Benitez-Burraco, A., Blanco-Portales, R., Redondo-Nevado, J., Bellido, M.L., Moyano, E., Caballero, J.L., Munoz-Blanco, J., 2003. Cloning and characterization of two ripening-related strawberry (Fragaria $x$ ananassa $\mathrm{cv}$ Chandler) pectate lyase genes. J. Exp. Bot. 54, 633-645.

Bonghi, C., Ferrarese, L., Ruperti, B., Tonutti, P., Ramina, A., 1998. Endo-beta1,4-glucanases are involved in peach fruit growth and ripening, and regulated by ethylene. Physiol. Plant. 102, 346-352.

Brummell, D.A., 2006. Cell wall disassembly in ripening fruit. Funct. Plant Biol. 33, 103-119.

Brummell, D.A., Dal Cin, V., Crisosto, C.H., Labavitch, J.M., 2004. Cell wall metabolism during maturation, ripening and senescence of peach fruit. $\mathrm{J}$. Exp. Bot. 55, 2029-2039.

Dal Cin, V., Rizzini, F.M., Botton, A., Tonutti, P., 2006. The ethylene biosynthetic and signal transduction pathways are differently affected by 1-MCP in apple and peach fruit. Postharvest Biol. Technol. 42, 125-133.

Downs, C.G., Brady, C.J., Gooley, A., 1992. Exopolygalacturonase protein accumulates late in peach fruit ripening. Physiol. Plant. 85, 133 140.

El-Sharkawy, I., Jones, B., Gentzbittel, L., Lelievre, J.M., Pech, J.C., Latché, A., 2004. Differential regulation of ACC synthase genes in cold-dependent and -independent ripening in pear fruit. Plant Cell Environ. 27, 11971210.

El-Sharkawy, I., Jones, B., Li, Z.G., Lelievre, J.M., Pech, J.C., Latché, A., 2003. Isolation and characterization of four ethylene perception elements and their expression during ripening in pears (Pyrus communis L.) with/without cold requirement. J. Exp. Bot. 54, 1615-1625.

Gamberini, A., 2007. Molecular markers and controlling genes of peach flesh texture. PhD thesis, University of Bologna, Italy.

Giovannoni, J.J., 2004. Genetic regulation of fruit development and ripening. Plant Cell 16, S170-S180.

Giovannoni, J.J., 2007. Fruit ripening mutants yield insights into ripening control. Curr. Opin. Plant Biol. 10, 283-289.

Guo, H.W., Ecker, J.R., 2004. The ethylene signaling pathway: new insights. Curr. Opin. Plant Biol. 7, 40-49.

Haji, T., Yaegaki, H., Yamaguchi, M., 2001. Changes in ethylene production and flesh firmness of melting, nonmelting and stony hard peaches after harvest. J. Jpn. Soc. Hort. Sci. 70, 458-459.

Haji, T., Yaegaki, H., Yamaguchi, M., 2004. Varietal differences in the relationship between maturation characteristics, storage life and ethylene production in peach fruit. J. Jpn. Soc. Hort. Sci. 73, 97-104.

Haji, T., Yaegaki, H., Yamaguchi, M., 2005. Inheritance and expression of fruit texture melting, non-melting and stony hard in peach. Sci. Hort. 105, 241-248.

Hayama, H., Shimada, T., Fujii, H., Ito, A., Kashimura, Y., 2006a. Ethyleneregulation of fruit softening and softening-related genes in peach. J. Exp. Bot. 57, 4071-4077.

Hayama, H., Shimada, T., Haji, T., Ito, A., Kashimura, Y., Yoshioka, H., 2000. Molecular cloning of a ripening-related expansin cDNA in peach: evidence for no relationship between expansin accumulation and change in fruit firmness during storage. J. Plant Physiol. 157, 567-573.

Hayama, H., Tatsuki, M., Ito, A., Kashimura, Y., 2006b. Ethylene and fruit softening in the stony hard mutation in peach. Postharvest Biol. Technol. 41, 16-21.

Hua, J., Meyerowitz, E.M., 1998. Ethylene responses are negatively regulated by a receptor gene family in Arabidopsis thaliana. Cell 94, 261-271.

Klee, H.J., 2002. Control of ethylene-mediated processes in tomato at the level of receptors. J. Exp. Bot. 53, 2057-2063.

Leclercq, J., Adams-Phillips, L.C., Zegzouti, H., Jones, B., Latché, A., Giovannoni, J.J., Pech, J.C., Bouzayen, M., 2002. LeCTR1, a tomato CTR1-like 
gene, demonstrates ethylene signaling ability in Arabidopsis and novel expression patterns in tomato. Plant Physiol. 130, 1132-1142.

Lelievre, J.M., Latché, A., Jones, B., Bouzayen, M., Pech, J.-C., 1997. Ethylene and fruit ripening. Physiol. Plant. 101, 727-739.

Ma, N., Tan, H., Xue, J.H., Li, Y.Q., Gao, J.P., 2006. Transcriptional regulation of ethylene receptor and CTR genes involved in ethylene-induced flower opening in cut rose (Rosa hybrida) cv Samantha. J. Exp. Bot. 57, 2763-2773.

Muller, R., Owen, C.A., Xue, Z.T., Welander, M., Stummann, B.M., 2002. Characterization of two CTR-like protein kinases in Rosa hybrida and their expression during flower senescence and in response to ethylene. J. Exp. Bot. 53, 1223-1225

Pfaffl, M.W., 2001. A new mathematical model for relative quantification in real-time RT-PCR. Nucleic Acid Res. 29, 2002-2007.

Ramina, A., Tonutti, P., McGlasson, B., 2007. Ripening and post-harvest physiology. In: The Peach, CABI, in press.

Rasori, A., Ruperti, B., Bonghi, C., Tonutti, P., Ramina, A., 2002. Characterization of two putative ethylene receptor genes expressed during peach fruit development and abscission. J. Exp. Bot. 53, 2333-2339.

Ruperti, B., Bonghi, C., Rasori, A., Ramina, A., Tonutti, P., 2001. Characterization and expression of two members of the peach 1aminocyclopropane-1-carboxylate oxidase gene family. Physiol. Plant. 111, 336-344.

Sambrook, J., Fritsch, E.F., Maniatis, T., 1989. Molecular Cloning: A Laboratory Manual, 2nd ed. Cold Spring Harbor Laboratory Press, Cold Spring Harbor, New York.

Tatsuki, M., Haji, T., Yamaguchi, M., 2006. The involvement of 1aminocyclopropane-1-carboxylic acid synthase isogene, $\mathrm{Pp}-\mathrm{ACS} 1$, in peach fruit softening. J. Exp. Bot. 57, 1281-1289.
Tonutti, P., Bonghi, C., Ramina, A., 1996. Fruit firmness and ethylene biosynthesis in three cultivars of peach (Prunus persica L. Batsch). J. Hort. Sci. $71,141-147$.

Tonutti, P., Bonghi, C., Ramina, A., et al., 2007. Modulating effects of ethylene and ethylene inhibitors in the control of fruit ripening. In: Ramina, A., Chang, C., Giovannoni, J., Klee, H., Perata, P., Woltering, E. (Eds.), Advances in Plant Ethylene Research: Proceedings of the 7th International Symposium on the Plant Hormone Ethylene. Springer, pp. 407415 .

Tonutti, P., Casson, P., Ramina, A., 1991. Ethylene biosynthesis during peach fruit development. J. Am. Soc. Hort. Sci. 116, 274-279.

Trainotti, L., Bonghi, C., Ziliotto, F., Zanin, D., Rasori, A., Casadoro, G., Ramina, A., Tonutti, P., 2006a. The use of microarray $\mu$ PEACH1 0 to investigate transcriptome changes during transition from pre-climacteric to climacteric phase in peach fruit. Plant Sci. 170, 606-613.

Trainotti, L., Pavanello, A., Zanin, D., 2006b. PpEG4 is a peach endo- $b-1,4-$ glucanase gene whose expression in climacteric peaches does not follow a climacteric pattern. J. Exp. Bot. 57, 589-598.

Trainotti, L., Zanin, D., Casadoro, G., 2003. A cell wall-oriented genomic approach reveals a new and unexpected complexity of the softening in peaches. J. Exp. Bot. 389, 1821-1832.

Wang, J., Chen, G., Hu, Z., Chen, X., 2007. Cloning and characterization of the EIN2-homology gene LeEIN2 from tomato. DNA Seq. 18, 3338.

Zhu, H.L., Zhu, B.Z., Shao, Y., Wang, X.G., Lin, X.J., Xie, Y.H., Li, Y.C., Gao, H.Y., Luo, Y.B., 2006. Tomato fruit development and ripening are altered by the silencing of LeEIN2 gene. J. Int. Plant Biol. 48, 14781485 . 